\title{
SINTESIS DAN UJI AKTIVITAS ANALGETIKA-ANTIINFLAMASI SENYAWA N-(4t-BUTILBENZOIL)-p-AMINOFENOL
}

\author{
Sri Sutji Susilowati, Santi Nur Handayani \\ Jurusan Kimia, Program Sarjana MIPA Unsoed Purwokerto
}

\begin{abstract}
The synthesis of N-4t-butyl benzoil-p-aminophenol has been done by reacting $\mathrm{p}$ aminophenol and $\mathrm{N}-4 \mathrm{t}$-butyl benzoil chloride compounds, then the products were isolated and analyzed by TLC, melting point determination, UV/Vis Spectrofotometry, infra red spectrofotometry and mass spectrometry. The synthesis yield of N-4t-butylbenzoil-paminophenol was $33,52 \%$, with the compound melting point between $192-194{ }^{\circ} \mathrm{C}$

The determination of analgesic ( $\mathrm{ED}_{50}$ of $\%$ analgesic activity ) and anti inflammatory activity $\left(\mathrm{ED}_{50}\right.$ of edema inhibition) gave the $\mathrm{ED}_{50}$ of $\%$ analgesic activity was $144 \mathrm{mg} / \mathrm{kg}$ and $\mathrm{ED}_{50}$ of \% edema inhibition was $43,24 \mathrm{mg} / \mathrm{kg}$.
\end{abstract}

Keywords : Synthesis, $N$-4t-butyl benzoil-p-aminophenol compound, analgesic activity, antiinflammatory activity

\section{PENDAHULUAN}

Sintesis merupakan bagian yang terpenting dalam pencarian senyawa obat baru yang mempunyai khasiat lebih baik dan harga yang lebih ekonomis. Sintesis dilakukan dengan penggabungan molekul, pengubahan gugus fungsi atau penutupan gugus yang bersifat toksigenik senyawa penuntun yang telah diketahui khasiat atau aktivitas biologinya. Senyawa penuntun bisa berasal dari tumbuhan, hewan, mikroba atau hasil sintesis. Salah satu senyawa penuntun yang mempunyai aktivitas analgetika adalah p-aminofenol.

$$
\text { Senyawa p-aminofenol }
$$
merupakan suatu senyawa analgetika kuat dan antiinflamasi lemah yang sangat toksik. Hal yang perlu dilakukan untuk mengurangi toksisitas dan menambah aktivitasnya dilakukan modifikasi molekul yaitu pengubahan atau penambahan gugus fungsi yang terdapat pada p-aminofenol. Pengubahan dapat dilakukan pada gugus amino, pada gugus hidroksi fenolik atau pada kedua gugus amino dan hidroksi fenolik (Willette, 1982).
Modifikasi molekul p-aminofenol sudah banyak dilakukan diantaranya ialah pengubahan gugus amina misalnya parasetamol, pengubahan gugus $\mathrm{OH}$ fenolik misalnya anisidin dan fenaldin. Pengubahan pada gugus amina dan $\mathrm{OH}$ misalnya fenasetin dan laktilfenetidin. Adapun struktur senyawa hasil modifikasi dapat dilihat seperti dalam Gambar 1 :

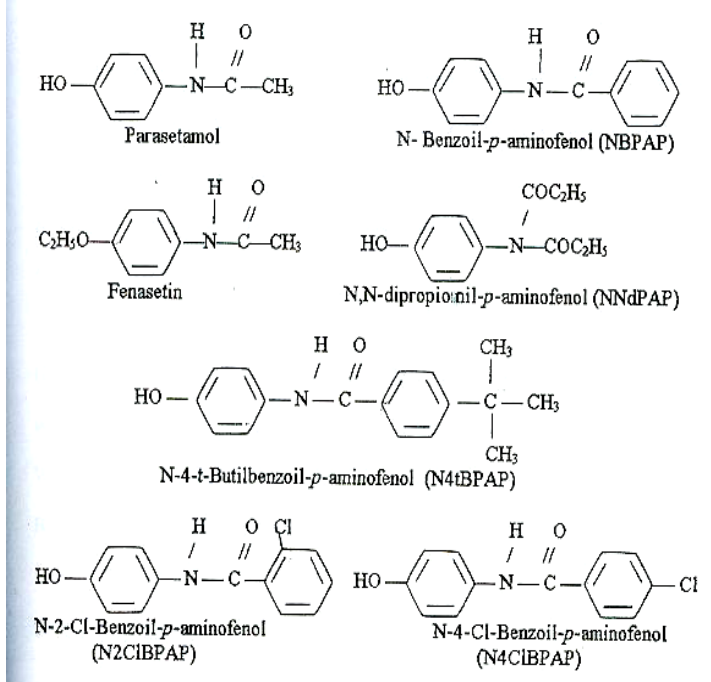

Gambar 1. Modifikasi molekul senyawa p-amino fenol 
Substitusi metil dan propil pada gugus amina parasetamol diperoleh senyawa N-metilparasetamol (log $\mathrm{P}=0,61) \quad$ dan $\quad \mathrm{N}, \mathrm{N}$-dipropionil-paminofenol $(3,41)$ yang berkhasiat analgetika (Pujono, 1984). Substitusi alkilhalida rantai panjang pada gugus amina menghasilkan senyawa yang mempunyai khasiat anti kanker (Springer, 1995). Benzoilasi gugus amina paminofenol dengan benzoilklorida dan 2klorobenzoilklorida diperoleh senyawa $\mathrm{N}$-benzoil-p-aminofenol $(\log \mathrm{P}=2,18)$ dan N-2-klorobenzoil-p-aminofenol (log $\mathrm{P}=2,8$ ) yang mempunyai aktivitas analgetik-antiinflamasi (Susilowati dan Chasani, 2003). Dari beberapa senyawa turunan p-aminofenol yang telah disintesis ternyata yang berkhasiat sebagai antiinflamasi adalah senyawa yang mempunyai lipofilisitas tinggi (log $\mathrm{P}>1,8$ ). Sifat lipofilik dan elektronik berperan pada proses penembusan membran dan interaksi obat reseptor (Soekardjo, 1997). Hal yang perlu dilakukan untuk mendapatkan senyawa analgetik-antiinflamasi yang lebih baik maka dilakukan sintesis N-4tbutilbenzoil-p-aminofenol $(\log \mathrm{P}=4,15)$ dengan mereaksikan p-aminofenol dan 4t-butilbenzoilklorida. Diharapkan dengan bertambahnya lipofilisitas senyawa akan memperbaiki efek antiinflamasinya.

\section{METODE PENELITIAN}

\section{Bahan dan Alat:}

\section{Bahan}

p-aminofenol (E.Merck), 4tbutilbenzoilklorida (E.Merck), asam asetat glasial (E.Merck), etanol p.a.(E.Merck), metanol p.a.(E.Merck), Kieselgel GF 254 (E.Merck), etanol $\left(\mathrm{C}_{2} \mathrm{D}_{5} \mathrm{OD}\right), \quad$ karboksimetilselulosa (E.Merck), karagenan (Sigma), parasetamol (Sigma), natrium diklofenak (Sigma).

\section{Hewan uji}

tikus putih jantan Ratus norwegitus galur Wistar berat 100 - 150 gram, mencit jantan Mus musculus galur Swiss berat 25 -35 gram.

\section{Alat}

Seperangkat alat gelas, jarum suntik, alat KLT, alat penentu titik leleh electrothermal lampu UV, spektrofotometer UV/Vis MR Spectronic 3000, spektofotometer infra merah Shimadzu FTIR-8201, dan spektrometer massa GC-MS (Shimadzu), alat pletismometer.

\section{Prosedur Kerja}

\section{Sintesis N- 4t- butilbenzoil- p- aminofenol}

Sepuluh gram p-aminofenol dilarutkan dalam $10 \mathrm{~mL}$ etanol kemudian direaksikan dengan $10 \mathrm{~mL}$ larutan 4tbutilbenzoilklorida dalam etanol $10 \%$ (v/v). Hasil reaksi disaring dengan corong Buchner, dikeringkan. Kemudian direkristalisasi dengan etanol panas. Hasil diuji kemurniannya dengan KLT (larutan pengembang metanol-air 60:40 dan 80:20, penampak noda lampu UV) dan penentuan titik leleh, kemudian dilakukan identifikasi dengan spektrometer UV, IR, NMR dan spektrometer massa.

\section{Uji aktivitas analgetika}

Aktivitas analgetika ditentukan dengan metode geliat asetat pada mencit menurut Witkin (Turner, 1965), sebagai pembanding digunakan parasetamol yang mempunyai aktivitas analgetika. Dalam setiap senyawa uji diperlukan 30 mencit jantan dengan 25-35 gram yang telah dipuasakan semalam, senyawa uji diberikan dalam bentuk suspensi dalam karboksi metilselulosa (CMC) 0,5\% secara oral, kadar obat dibuat bervariasi antara $1-3 \% \mathrm{~b} / \mathrm{v}$ agar suspensi yang diberikan tidak lebih dari 0,5 mL. Mencit dibagi menjadi 5 kelompok, kemudian diberi suspensi senyawa uji dengan dosis 0 (kontrol), 20, 40, 80 dan $160 \mathrm{mg} / \mathrm{kg}$ berat badan. Lima belas menit kemudian diberi larutan asam asetat $1 \% \quad(\mathrm{v} / \mathrm{v})$ 
dengan dosis $300 \mathrm{mg} / \mathrm{kg}$ berat badan secara intra-peritoneal (i.p). Geliat yang timbul dicatat setiap selang waktu 15 menit selama 1 jam. Daya analgetika dihitung dengan rumus:

$\%$ daya analgetika $=100-(\mathrm{P} / \mathrm{K} \times 100)$

$\mathrm{P}=$ jumLah kumulatif geliat mencit yang diberi senyawa uji;

$\mathrm{K}=$ jumLah kumulatif geliat mencit kontrol.

\section{Uji aktivitas antiinflamasi}

Aktivitas antiinflamasi ditentukan dengan metode penghambatan edema yang diinduksi karagenan pada tikus menurut Winter, sebagai pembanding digunakan natrium diklofenak yang mempunyai aktivitas antiinflamasi. Dalam tiap senyawa uji diperlukan 20 ekor tikus wistar jantan berat $100-150$ gram yang telah dipuasakan semalam, diberi tanda pada kakinya, kemudian dibagi menjadi 4 kelompok dengan diberi senyawa uji 0, 40, 60 dan $80 \mathrm{mg} / \mathrm{kg}$ berat badan secara oral. Satu jam setelah pemberian senyawa uji, pada jaringan plantar telapak kaki kanan tikus disuntikkan suspensi karagenan $1 \% \mathrm{~b} / \mathrm{v}$ sebanyak 0,1 mL secara subkutan. Segera setelah penyuntikan, kaki tikus dimasukkan sampai tanda ke dalam alat pletismometer, kemudian diukur perubahan volume air raksa yang disebabkan oleh edema kaki tikus. Pengukuran dilakukan tiap jam dimulai dari jam ke 0 sampai jam ke 3. Prosentase beda volume edema dihitung dengan rumus:

Dvt $=(\mathrm{Vt}-\mathrm{Vo}) / \mathrm{Vo} \times 100 \%$

$\mathrm{Vo}=$ volume edema $(\mathrm{mL})$ pada jam ke 0 , $\mathrm{Vt}=$ volume edem pada jam ke $\mathrm{t}$.

Dari data beda volume edema dihitung prosentase hambatan edema ( $\%$ inhibisi) tiap jam untuk tiap kelompok dengan rumus:

$$
\% \text { inhibisi }=\left\{1-\left(\mathrm{V}_{\mathrm{T}} / \mathrm{V}_{\mathrm{K}}\right)\right\} \times 100
$$

$\mathrm{V}_{\mathrm{T}}=$ prosentase beda volume edema jam ke $\mathrm{t}$ kelompok dosis perlakuan,

$\mathrm{V}_{\mathrm{K}}=$ prosentase beda volume edema jam ke $\mathrm{t}$ kelompok kontrol.

\section{HASIL DAN PEMBAHASAN}

Diperoleh rendemen senyawa hasil sintesis sebesar 33,52\%,dengan titik leleh $192-194^{\circ} \mathrm{C}$.

Pada pemeriksaan KLT diperoleh hasil sebagai berikut: dengan larutan pengembang metanol-air 60:40 diperoleh $\mathrm{Rf}=0,84$ dan dengan larutan pengembang metanol air 80:20 diperoleh $\mathrm{Rf}=0,88$. Dari spektra uv senyawa dalam etanol diperoleh 3 puncak yaitu pada panjang gelombang 204, 226 dan $283 \mathrm{~nm}$ (Gambar 2)

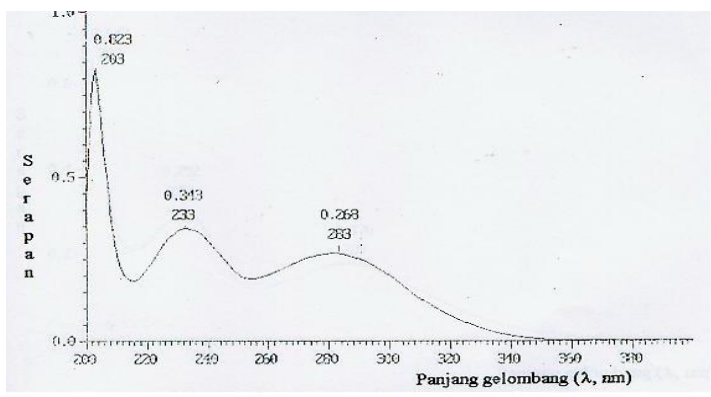

Gambar 2. Spektra uv senyawa hasil sintesis

Dari spektra infra merah senyawa hasil sintesis (dalam Gambar 3) diperoleh data sebagai berikut ( $v$ maks, $\mathrm{cm}^{-1}, \mathrm{KBr}$ ): 3670-3651 (O-H fenol), $3392 \quad(\mathrm{~N}-\mathrm{H}$ amida), 2960-2869 $\left(-\mathrm{CH}_{3}\right), 1625(\mathrm{C}=\mathrm{O}$, amida I), 1608-1436 (C=C, aromatik), $1515 \quad(\mathrm{C}=\mathrm{O}, \quad$ amida II $), \quad 1271-1215$ $\left(\mathrm{C}\left(\mathrm{CH}_{3}\right)_{3}\right), \quad 827$ (benzena tersubstitusi para).

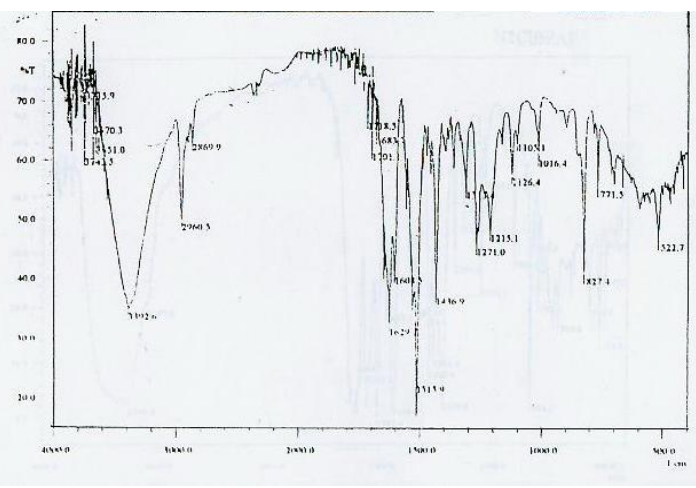

Gambar 3. Spektra infra merah senyawa hasil sintesis 
Dari spektra massa (Gambar 4) diperoleh data sebagai berikut $(\mathrm{EI} / \mathrm{m} / \mathrm{z})$ : $269 \quad\left(\mathrm{M}^{+}, \quad \mathrm{C}_{17} \mathrm{H}_{19} \mathrm{NO}^{+} ; \quad 20 \%\right), \quad 161$ $\left(\mathrm{C}_{11} \mathrm{H}_{13} \mathrm{O}^{+}, 100 \%\right), 146\left(\mathrm{C}_{10} \mathrm{H}_{10} \mathrm{O}^{+}, 12 \%\right)$, $118\left(\mathrm{C}_{9} \mathrm{H}_{10}{ }^{+}, 12 \%\right), 91\left(\mathrm{C}_{7} \mathrm{H}_{7}{ }^{+}, 12 \%\right), 77$ $\left(\mathrm{C}_{6} \mathrm{H}_{5}^{+}, 8 \%\right)$.

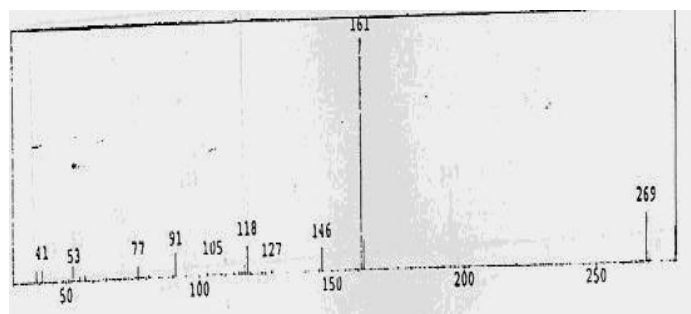

Gambar 4. Spektra massa senyawa hasil sintesis

Fragmentasi senyawa hasil sintesis dapat dilihat pada Gambar 5.

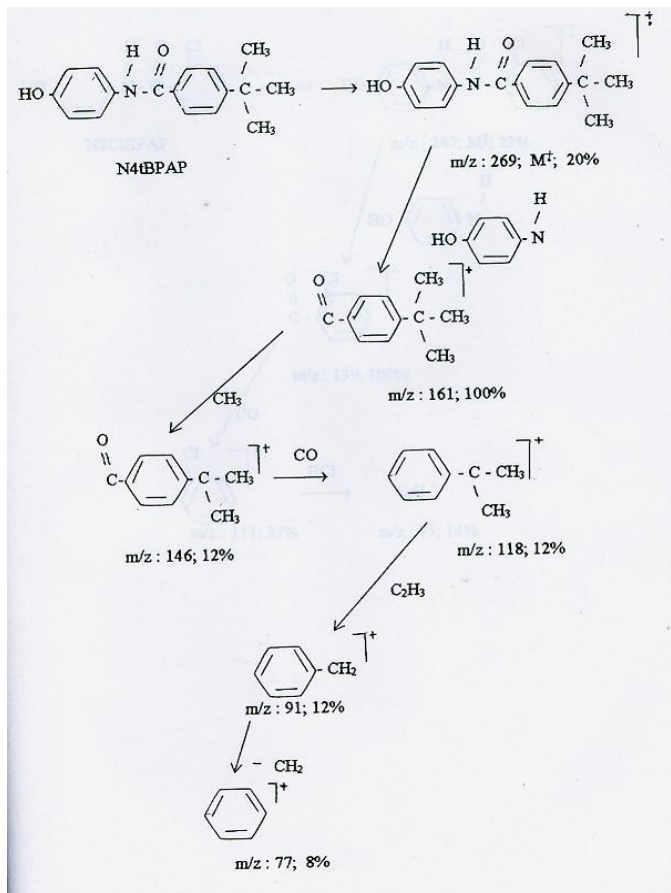

Gambar 5. Fragmentasi senyawa hasil sintesis

Dari data titik leleh ternyata senyawa yang terbentuk mempunyai titik leleh yang berbeda dengan senyawa asal yaitu p-aminofenol $\left(\mathrm{t} .1 .=105^{\circ} \mathrm{C}\right)$ dan $4 \mathrm{t}$ butilbenzoilklorida. $\left(\mathrm{t} .1 .=61{ }^{\circ} \mathrm{C}\right)$. Data KLT menunjukkan bahwa hasil sintesis cukup murni dan mempunyai Rf yang berbeda dengan senyawa asal. Sedangkan dari data spektrum UV, IR dan spektra masa terlihat bahwa senyawa hasil sintesis berbeda dengan senyawa asal, dapat diambil kesimpulan bahwa telah terbentuk senyawa yang diinginkan yaitu N-4t-butilbenzoil-p-aminofenol.

Reaksi sintesis yang terjadi dapat dilihat dalam Gambar 6 di bawah ini :
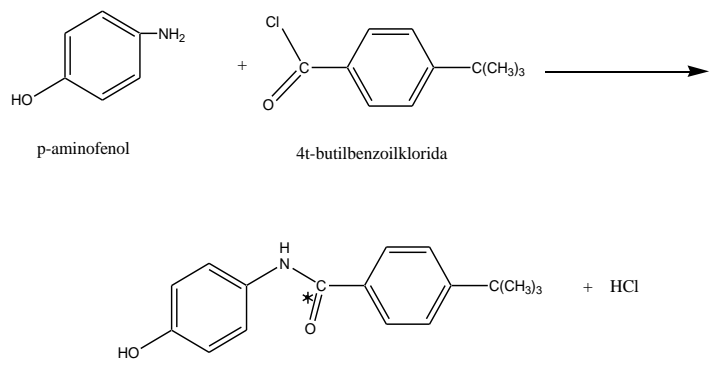

Gambar 6. reaksi sintesis senyawa N-4tbutilbenzoil-p-aminofenol

Jika dilihat dari rendemen yang kecil maka pada sintesis ini perlu diperhatikan $\mathrm{pH}$ nya. Sintesis pada $\mathrm{pH}$ rendah lebih baik dari sintesis pada $\mathrm{pH}$ tinggi karena pada $\mathrm{pH}$ tinggi dapat terbentuk senyawa ester.

Uji aktivitas analgetika senyawa hasil sintesis dibandingkan dengan parasetamol, menunjukkan bahwa senyawa N-4t-butilbenzoil-p-aminofenol mempunyai $\mathrm{ED}_{50}$ aktivitas analgetika sebesar $\quad 144 \mathrm{mg} / \mathrm{kg}$, sedangkan parasetamol mempunyai $\mathrm{ED}_{50}$ sebesar 95 $\mathrm{mg} / \mathrm{kg}$.

Uji aktivitas antiinflamasi senyawa hasil sintesis dibandingkan dengan natrium diklofenak, didapatkan $\mathrm{ED}_{50}$ hambatan edema senyawa hasil sintesis 43,24 $\mathrm{mg} / \mathrm{kg}$ sedangkan $\mathrm{ED}_{50}$ natrium diklofenak sebesar $23,43 \mathrm{mg} / \mathrm{kg}$.

\section{KESIMPULAN}

Dari penelitian yang telah dilakukan dapat diambil kesimpulan bahwa: 
1. Senyawa N-4t-butilbenzoil-paminofenol dapat disintesis dengan mereaksikan $\mathrm{p}$-aminofenol dengan 4tbutilbenzoilbenzoilklorida.

2. Senyawa hasil sintesis berkhasiat sebagai analgetika dan antiinflamasi, terbukti dengan makin bertambahnya lipofilisitas senyawa aktivitas antiinflamasinya semakin kuat.

3. Aktivitas sebagai analgetika lebih lemah dari parasetamol, sedangkan khasiat sebagai antiinflamasi lebih kuat dari parasetamol tetapi lebih lemah dari natrium diklofenak

\section{SARAN}

Perlu dilakukan sintesis senyawa N-4t-butilbenzoil-p-aminofenol dengan memperhatikan $\mathrm{pH}$ agar bisa didapatkan rendemen yang lebih banyak serta perlu dilakukan uji toksisitas senyawa hasil sintesis agar diketahui keamanan penggunaannya.

\section{DAFTAR PUSTAKA}

Pujono, 1984, Modifikasi Molekul Parasetamol dengan Menutupi Gugus Toksigenik (Untuk Menghambat Pembentukan Arilamin), Tesis Program Strata II, UGM, Yogyakarta.

Soekardjo, B., 1997, Sintesis dan Uji Aktivitas Antibakteri Senyawa 3,4diklorobenzoil-N-ampisillin,

Cermin Dunia Farmasi, 34,1997: 28-31.

Springer, J.C., 1995, Optimation of Alkyllting Agent Prodrug Derived from Phenol and Anilin Mustardas: A New Candidate Prodrug (ZZD 2767) for Antibody -Directed Enzyme Prodrug Therapy (ADEPT), J. Med. Chem., 38,26: 5051-5065.

Susilowati, S.S. dan Chasani, M., 2003, Sintesis Senyawa Turunan $p$ - aminofenol Serta Uji Aktivitas Analgetika dan Antiinflamasinya Pada Mencit dan Tikus Putih. Laporan Penelitian SPP/DPP Universitas Jenderal Soedirman, Purwokerto.

Turner, R.A., 1965, Screening Methods in Pharmacology, Academic Press, New York, 100-113, 233-234.

Willette, R.E., 1982, Analgesic Agents, dalam J.N. Delgado dan W. A. Remers (eds.) Wilson and Gisvold's Textbook of Organic Medicinal and Pharmacetical Chemistry, 8th Ed. J.B. Lippincott, Philadelphia, 637-652. 